\title{
Spiders of the Genus Laufeia (Araneae: Salticidae) from Japan
}

\author{
Hiroyoshi Ikeda ${ }^{1)}$ \\ 池田博明 ${ }^{1)}$ : 日本産コハエトリグモ属のクモ \\ (クモ目：ハエトリグモ科)
}

\begin{abstract}
A new salticid spider species, Laufeia sasakii sp. nov. is described on the basis of the materials obtained from Tokunoshima Island, Kagoshima Pref., Japan. Another species of the same genus, Laufeia aenea Simon, 1889, is redescribed.
\end{abstract}

Simon (1889) described six new species of spiders based on the specimens collected by Mellottée from Yokohama City, Kanagawa Pref., Japan, and established three new genera, Laufeia, Siler and Tricca. The former two genera belong to salticid spiders, and the last genus belong to lycosid spiders.

Up to the present, six species of the genus Laufeia were described in the world (Prószyński 1990). However, some of them may be not congeneric, and hence further study is necessary (Żabka 1985, Bohdanowicz and Prószyński 1987).

When I examined the spider specimens collected by Takeshi Sasaki from Tokunoshima Island, Kagoshima Pref., Japan, I recognized a new species of the genus Laufeia in the specimens. The species resembles Laufeia aenea Simon, 1889, however the previous description of the latter species was not adequate for some errors such as leg length (Simon 1889), male palps (Yaginuma 1986, Bohdanowicz and Prószyński 1987). These two species will be described in the present paper.

The type specimens designated in this paper are deposited in the collection of the Department of Zoology, National Science Museum (Nat. Hist.), Tokyo.

The following abbreviations are used: ALE, anterior lateral eye; AME, anterior median eye; PLE, posterior lateral eye; PME, posterior median eye. The distances between eyes are presented with a dash, e.g., ALE-ALE indicates distance between ALEs.

\section{Genus Laufeia Simon, 1889}

Laufeia Simon, 1889: 248. Type species: Laufeia aenea Simon, 1889 on the basis of the male specimen from Yokohama City, Japan.

Diagnosis. Small spiders with scutum on the opisthosoma, total length about 3.6 $\mathrm{mm}$, colored with dark brown. Prosoma: cephalic part flat, shinny, posterior thoracic part declined. Eyes: AME $>$ ALE $>$ PLE $>$ PME. [PLE $>$ ALE (Yaginuma 1986), in-

1) Kanade 1099, Oimachi, Ashigarakami-gun, Kanagawa, 258-0018 Japan

干 258-0018 神奈川県足柄上郡大井町金手 1099

Accepted June 8, 1998 
correct] ALE-ALE > PLE-PLE. Anterior eyes very close to each other, anterior eye row recurved. PME positioned in the midst between ALE and PLE. Chelicera robust and not so long, with its retromargin fissident and with bicuspid tooth. Labium: almost square, as long as broad. Sternum: broad between coxae, parallel on sides, anteriorly not attenuated. Opisthosoma: oval, with scutum. Male palpal organ with a meandering canal on the surface of bulbs as same as the genus Euophrys, and with a twisted embolus, conductor and with a single tibial apophysis. Spermathecae of female in the form of oval reservoirs. Legs, robust and short. Length of legs: I $>$ IV $>$ III $>$ II in male [I $>$ IV $>$ II $>$ III (Simon 1889), incorrect, leg III slightly longer than leg II], IV $>$ I $>$ III $>$ II in female. Legs I and II: tibiae and metatarsi armed with 2-2 ventral spines (sometimes ventro-prolateral spine missing) and without dorso-lateral spines. Legs III and IV: tibiae of male with or without a few dorso-lateral spines and metatarsi with apical spines.

Distribution. Japan, China, Java, Sumatra, Malaysia, Vietnum and New Zealand (Prószyński 1990).

Laufeia aenea Simon, 1889.

Laufeia aenea Simon, 1889, p. 248. —— Matsumoto, 1976, p. 34, figs. 11-14.—Prószyński, 1976, figs. 103, 136, map 108.-Hu, 1984, p. 371, figs. 387, 1-2. - Yaginuma, 1986, p. 241, fig. 133, 3p [the embolus and the bulb of the male palp are incorrect], 3e.-Bohdanowicz and Prószyński, 1987, p. 74-76, figs.84-89.

Specimens examined. 1 ठठ , Hachioji-joshi, Hachioji-shi, Tokyo, 16-VII-1989, K. Kumada leg. (NSMT-Ar 3787). 1 우, Koma-yama, Oiso-machi, Kanagawa pref., 4-VI1991, S. Enju leg. (NSMT-Ar 3788). 1 ठ 万’, Naruto-machi, Chiba Pref., 28-VI-1997, Y. Kudo leg.; 1 우, Guzo, Yamato-shi, Kanagawa pref., 23-V-1993, H. Ikeda leg.; 1 우, Kamiwada, Yamato-shi, Kanagawa Pref., 11-V-1992, H. Ikeda leg.; 1 우, Iiyama, Atsugi-shi, Kanagawa Pref., 12-VII-1979, K. Kumada leg.; 1 ऽ, Asamizodai,

Table 1. Measurement of leg segments of Laufeia aenea Simon, 1889.

\begin{tabular}{ccccccc}
\hline Leg & Femur & Patella & Tibia & Metatarsus & Tarsus & Total \\
\hline I & $1.07 / 0.90$ & $0.69 / 0.53$ & $0.85 / 0.60$ & $0.58 / 0.40$ & $0.37 / 0.37$ & $3.56 / 2.80$ \\
II & $0.85 / 0.77$ & $0.50 / 0.40$ & $0.57 / 0.50$ & $0.42 / 0.42$ & $0.35 / 0.29$ & $2.69 / 2.38$ \\
III & $0.87 / 0.87$ & $0.40 / 0.42$ & $0.58 / 0.58$ & $0.57 / 0.58$ & $0.37 / 0.38$ & $2.79 / 2.83$ \\
IV & $1.00 / 0.94$ & $0.50 / 0.50$ & $0.72 / 0.68$ & $0.60 / 0.58$ & $0.37 / 0.37$ & $3.19 / 3.07$ \\
\hline
\end{tabular}

Table 2. Spinations of legs of Laufeia aenea Simon, 1889. (dorsal/ ventral, none $=$ no spine, $\mathrm{p}=$ prolateral, $\mathrm{r}=$ retrolateral).

\begin{tabular}{rlll}
\hline Leg & \multicolumn{1}{c}{ Femur } & \multicolumn{1}{c}{ Tibia } & \multicolumn{1}{c}{ Metatarsus } \\
\hline Io & $0-1 \mathrm{p}-1 \mathrm{p}-2 \mathrm{p} /$ none & none $/ 1 \mathrm{r}-2-2$ & none $/ 2-2$ \\
우 & $0-1 \mathrm{p}-1 \mathrm{p}-1 \mathrm{p} /$ none & none $/ 1 \mathrm{r}-2-2$ & none $/ 2-2$ \\
II o & $0-1 \mathrm{p}-1 \mathrm{p}-2 \mathrm{p} /$ none & none $/ 1 \mathrm{r}-2-2$ & none $/ 2-2$ \\
우 & $0-1 \mathrm{p}-1 \mathrm{p}-1 \mathrm{p} /$ none & none $/ 1 \mathrm{r}-2-2$ & none $/ 2-2$ \\
III o' & $0-1-1-2 \mathrm{p} \cdot 1 \mathrm{r} /$ none & $2-2-0 / 0-0-2$ & none $/ 1 \mathrm{p}-2 \mathrm{p} \cdot 2 \mathrm{r}$ \\
우 & $0-1-1-1 \mathrm{p} /$ none & none $/$ none & none $/ 0-2 \mathrm{p} \cdot 2 \mathrm{r}$ \\
IV o & $0-1 \mathrm{p}-1 \mathrm{p}-2 /$ none & $0-2-0 / 0-0-2 \mathrm{p}$ & none $/ 0-2 \mathrm{p} \cdot 2 \mathrm{r}$ \\
우 & $0-1-1-1 /$ none & none $/$ none & none $/ 0-2$ \\
\hline
\end{tabular}




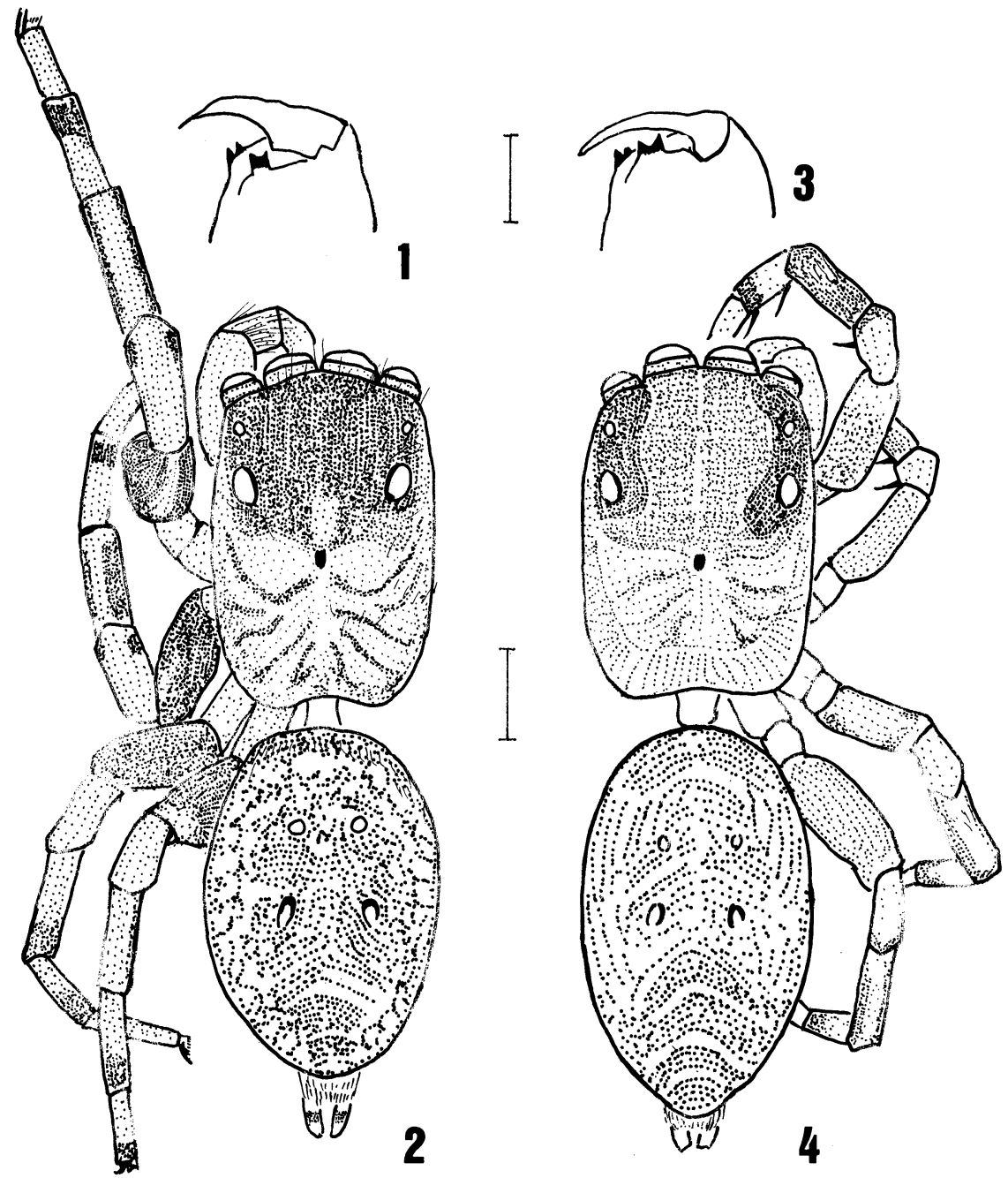

Figs. 1-4. Laufeia aenea Simon,1889. — 1, Male, cheliceral tooth; 2, male, dorsal view; 3, female, chelitheral tooth; 4, female, dorsal view. (Scales:1 and 3;0.2 mm, 2 and $4,0.5 \mathrm{~mm}$ )

Sagamihara-shi, Kanagawa Pref., 20-VII-1997, M. Imai leg.; 1 우, Shinsei-ko Lake, Hadano-shi, Kanagawa Pref., 4-VIII-1993, T. Maekawa leg.; 1 ठ awa Pref., A. Tanikawa leg. 3 아 우 1, Kissho, Minami-izu-cho, Shizuoka Pref., 25-VII1992, K. Kumada leg.; 1 ơ 1 우 2nymphs, Kumano-shi, Mie Pref., 24 - 25-VII-1993, H. Ikeda leg.; 1 우 (with waxy mating plug), Mt. Kosho, Amagi-cho, Fukuoka Pref., 16-VI-1985, S. Nomura leg.; 1 우, Momiki, Izumi-mura, Kumamoto Pref., 29-VII-1995, T.Irie leg.; 1 ㅇ, Yakushima Island, Kagoshima Pref., 22-VIII-1952, C. Okuma leg.

Description. Measurement of the specimens from Hachioji-shi, Tokyo (NSMT 

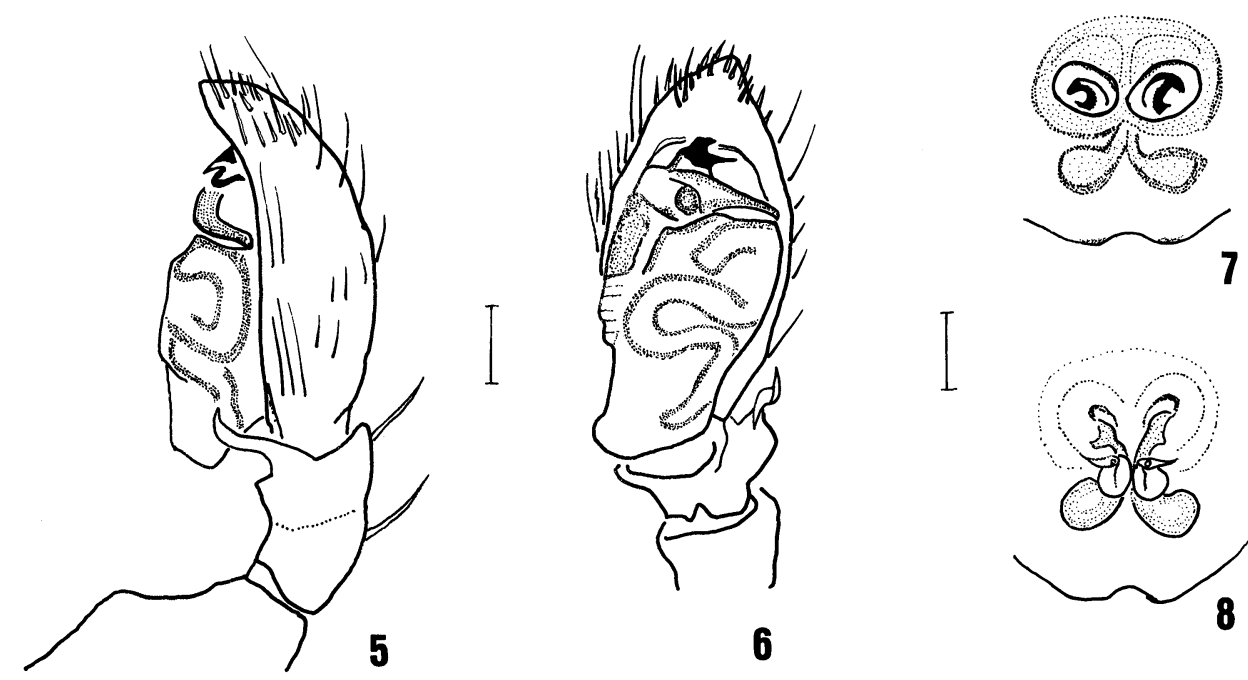

Figs. 5-8. Laufeia aenea Simon, 1889. 5 , Male palp, retrolateral view; 6 , same, ventral view; 7, epigynum, ventral view; 8 , female genitalia, dorsal view. (Scales: $0.2 \mathrm{~mm})$.

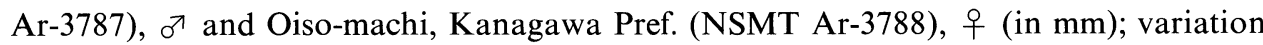
in parentheses. Body length or 4.21 (3.09-4.21), 우 4.09 (3.42-4.38); prosoma length $\sigma^{7}$ 1.88 (1.46-1.88) 우 $1.86(1.67-1.88)$, width o 1.37 (1.08-1.37), 우 1.33 (1.25-1.46), height o7 $0.83(0.56-0.83)$, 우 $0.83(0.67-0.88)$; opisthosoma length ơ 2.09 (1.62-2.09), 우 2.21 (1.63-2.67), width or $1.42(1.33-1.42)$, 우 $1.46(1.33-1.79)$. Eye fields: ALEALE 이 1.14 (0.90-1.14), 우 1.15 (1.05-1.17), PLE-PLE o 乃 $^{7} 1.02$ (0.84-1.02), 우 1.04 (0. 94-1.13), ALE-PLE ơ 0.72 (0.57-0.72), 우 0.79 (0.68-0.79), ALE-PME ơ 0.37 (0.30$0.37)$, 우 $0.42(0.36-0.42)$; AME diameter 자 $0.34(0.32-0.34)$, 우 $0.33(0.20-0.33)$, ratio ALE/AME 구 0.68 (0.63-0.68), 우 0.70 (0.63-0.70), ALE/PLE 구 1.40 (1.13-1.40), 우 1.27 (1.14-1.30), PME/PLE o7 $0.20(0.20-0.35)$, 우 $0.27(0.26-0.30)$. Legs. Length of legs of the specimens from Hachioji-shi, Tokyo, o $\sigma^{7}$ and Oiso-machi, Kanagawa Pref., 우, as shown in Table 1. Spination of legs of the same specimens as shown in Table 2.

Male palp (Figs.4-8,14). A meandering canal on the surface of the bulbs as same as those of the related genus Euophrys and a long thin twisted tibial apophysis present. Embolus twisted with a branched projection and a long curved process as conductor. Femur with a ventral apical protuberance.

Female genitalia (Figs. 9-11). Epigynum brown with two copulatory openings on the chitinous plate. Spermathecae small, globular, fertilization duct oval.

Coloration and markings (Figs. 1-4). Male: Prosoma brown to blackish brown with white hairs, surrounding of eyes black, AME and ALE fringed by white hairs. Fovea short, distinct. Clypeus brown, narrow, covered with white hairs. Chelicerae brown with a bicuspid tooth on retromargin. Sternum brown with sparse brown hairs. Opisthosoma: dorsum black and shiny brown clothed with white hairs and with a scutum; venter gray with sparse brown hairs. Legs I and II: femora and tibiae brown to dark brown, black laterally; patellae and tarsi brown; metatarsi brown. Legs III and 
IV: femora brown to dark brown, black laterally; patellae, tibiae and metatarsi brown, distally black; tarsi brown. Female: Same as in male, slightly paler.

Distribution. Japan (Honshu, Kyushu) and China.

Remarks. This species differs from the related species in the copulatory organ, especially in the branched process of the embolus and the X-shaped epigynum.

\section{Laufeia sasakii sp. nov.}

Specimens examined. Holotype: $\sigma^{7}$, Mikyo, Tokunoshima Island, Kagoshima Pref., 8-V-1996, T. Sasaki leg. (NSMT-Ar 3789). Paratype: $1 \sigma^{\nearrow}$, Same data as for the holotype. (NSMT-Ar 3790).

Description (female unknown). Measurement of the holotype (in $\mathrm{mm}$ ); measurement of the paratype in parentheses. Body length 4.00 (3.75); prosoma length 1.79 (1.71), width 1.40 (1.25), height 0.52 (0.63); opisthosoma length 2.09 (1.71), width 1.46 (1.21). Eye fields: ALE-ALE 1.10 (1.04), ALE-PLE 0.73 (0.67), PLE-PLE 0.99 (0.94), ALE-PME 0.37 (0.34); AME diameter 0.34 (0.33), ratio ALE/AME 0.68 (0.65), ALE/ PLE 1.40 (1.44), PME/PLE 0.30(0.33).

Legs. Length of legs of the holotype as shown in Table 3. Spination of legs of the same specimen as shown in Table 4.

Male palp (Figs. 11-13). Similar to that of Laufeia aenea, but the apical tip of long process as a conductor visible from the ventral side, with a embolus small, femur without ventral apical protuberance.

Coloration and markings (Figs.9-10). Almost same as the former species Laufeia aenea. Male: Prosoma brown and shiny, covered with white hairs, surrounding of eyes black, AME and ALE fringed by white hairs. Fovea short, distinct. Clypeus brown, narrow, covered with white hairs. Chelicerae brown with a bicuspid tooth on retromargin. Sternum brown with sparse brown hairs. Opisthosoma: dorsum shiny black clothed with white hairs and with scutum; venter gray with sparse brown hairs. Leg I: femur and tibia brown, black laterally; patella and tarsus brown; metatarsus brown, black distally. Legs II and III: femora brown, black laterally; patellae, tibiae and metatarsi brown, distally black; tarsi brown. Leg IV: femur pale brown; patella, tibia and metatarsus brown, distally black; tarsus brown.

Table 3. Measurement of leg segments of Laufeia sasakii sp., nov., (in mm).

\begin{tabular}{ccccccc}
\hline Leg & Femur & Patella & Tibia & Metatarsus & Tarsus & Total \\
\hline I & 1.04 & 0.68 & 0.84 & 0.50 & 0.38 & 3.44 \\
II & 0.67 & 0.48 & 0.53 & 0.50 & 0.33 & 2.51 \\
III & 0.85 & 0.42 & 0.57 & 0.48 & 0.37 & 2.69 \\
IV & 0.92 & 0.46 & 0.67 & 0.57 & 0.37 & 2.99 \\
\hline
\end{tabular}

Table 4. Spinations of legs of Laufeia sasakii sp. nov., (dorsal/ventral, none $=$ no spine, $\mathrm{p}=$ prolateral, $\mathrm{r}=$ retrolateral).

\begin{tabular}{rlll}
\hline Leg & Femur & Tibia & \multicolumn{1}{c}{ Metatarsus } \\
\hline I $\sigma^{\nearrow}$ & $0-1-1-1 \cdot 1 \mathrm{p} /$ none & none $/ 1 \mathrm{r}-2-2$ & none $/ 2-2$ \\
II $\sigma^{\nearrow}$ & $0-1-1-1 \cdot 1 \mathrm{p} /$ none & none $/ 1 \mathrm{r}-1 \mathrm{r}-2$ & none $/ 2-2$ \\
III $\sigma^{7}$ & $0-0-1-1 \cdot 1 \mathrm{p} /$ none & $0-2-0 / 0-0-1 \mathrm{p}$ & none $/ 0-2 \mathrm{p} \cdot 2 \mathrm{r}$ \\
IV $\sigma^{\nearrow}$ & $0-1-1-1 /$ none & $0-1 \mathrm{r}-0 /$ none & none $/ 0-2 \mathrm{p} \cdot 2 \mathrm{r}$ \\
\hline
\end{tabular}




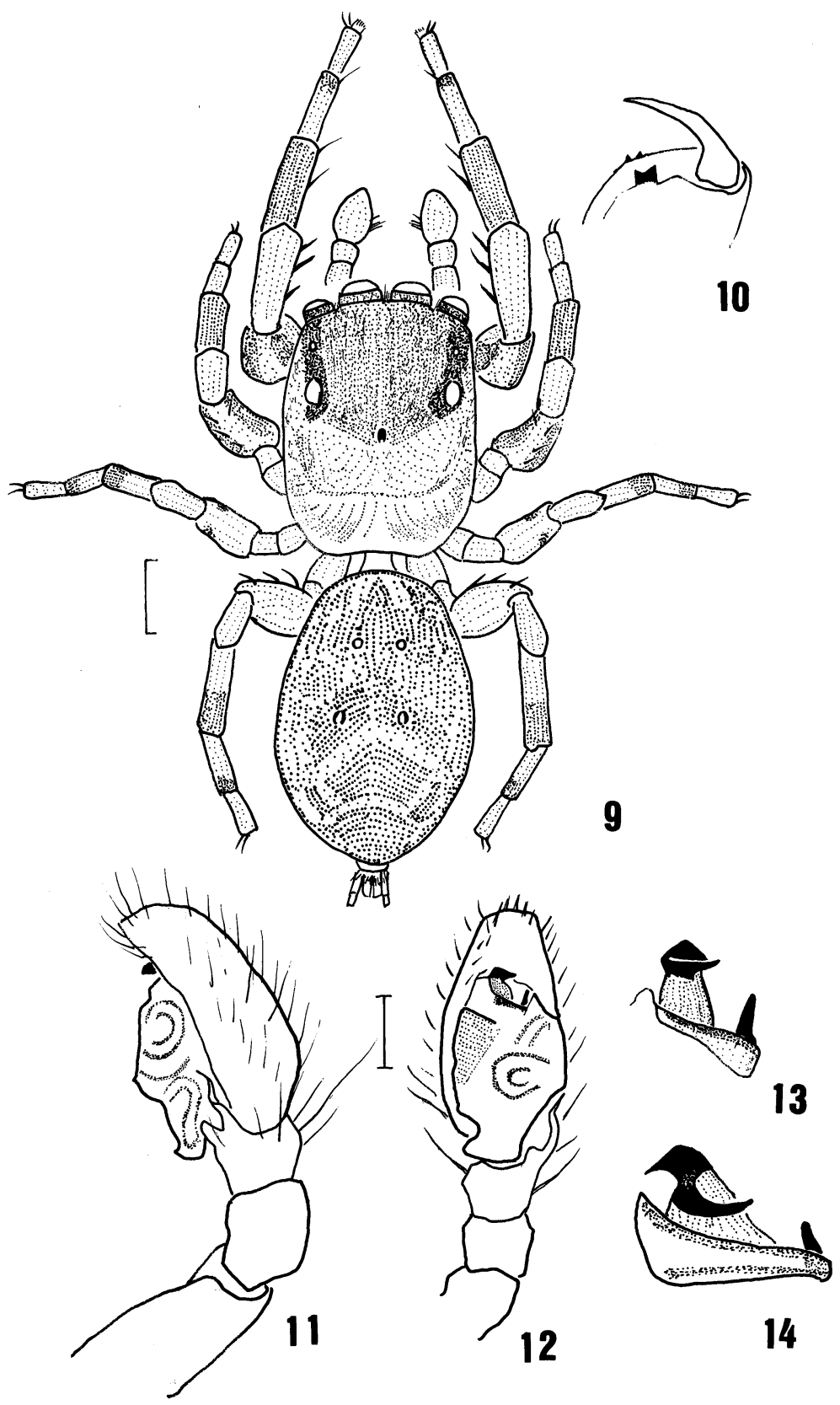

Figs. 9-14. 9-13. Laufeia sasakii sp. nov., 14. Laufeia aenea Simon, 1889. _ 9, Male, dorsal view (scale: $0.5 \mathrm{~mm}$ ); 10, male cheliceral tooth; 11, male palp, retrolateral view; 12, same, ventral view (scale: $0.2 \mathrm{~mm}$ ); 13, 14, conductor and embolus, ventral view. 
Distribution. Japan (known only from the type locality).

Remarks. Laufeia sasakii closely resembles Laufeia aenea, but can be distinguished from the latter by the structure of male palp, especially by the shape of the embolus and process of the conductor.

Etymology. This species is dedicated to Mr. Takeshi Sasaki who collected the specimens of the new species.

\title{
Acknowledgments
}

I wish to express my hearty thanks to Dr. Hirotsugu Ono, National Science Museum (Nat.Hist.), Tokyo, for his constant guidance and for critical reading the manuscript of this paper, to Mr. Akio Tanikawa, Kanagawa, Mr. Takeshi Sasaki, Okinawa , Mr. Takatoshi Maekawa, Kanagawa, Mr. Ken-ichi Kumada, Kanagawa, Mr. Masami Imai, Kanagawa, Mr. Shinji Enju, Kanagawa, Mrs. Yasue Kudo, Chiba, the late Dr. Chiyoko Okuma, Fukuoka, Mr. Teruo Irie, Kumamoto, for offering the specimens used in this paper, to Dr. Hozumi Tanaka, Osaka, for references.

\author{
摘 要 \\ 徳之島産の雄の標本に基づいて, Laufeia コハエトリグモ属の 1 新種 Laufeia sasakii \\ トクノシマエキスハエトリ(新種)を記載した他，エキスハエトリLaufeia aenea Simon, \\ 1889 を再記載して比較検討した。
}

\section{References}

Bohdanowicz,A. \& J. Prószyński, 1987. Systematic studies on East Palaearctic Salticidae (Araneae), IV. Salticidae of Japan. Ann. zool., Warszawa, 41: 43-151.

Hu, J. L., 1984. The Chinese Spiders Collected from the Fields and the Forests. 482 pp. 16 pls. Tianjin Press of Science and Techniques. (In Chinese.)

Matsumoto, S., 1976. Classification of Salticids (II). 7 species of salticids from Japan. Kishidaia, (40): 33-40.

Platnick, N. I., 1989. Advances in Spider Taxonomy, 1981-1987. 673 pp. Manchester University Press.

Prószyński, J., 1976. Studium systematyczno-zoogeograficzne nad rodzina Saticidae (Aranei) Regionow Palearktycznego I Nearktycznego. 260 pp. WSRP, Siedlce.

Prószyński, J., 1990. Catalogue of Salticidae (Araneae). 366 pp. WSRP, Siedlce.

Simon, E., 1889. Descriptions de quelques especes recuellies au Japon par A. Mellotee. Ann. Soc. Entmol. France, Ser. 6, 8: 248-252.

Yaginuma, T., 1986. Spiders of Japan in color (n. ed.). 305 pp. 64 pls. Hoikusha, Osaka. (In Japanese.)

Zabka, M., 1985. Systematic and zoogeographic study on the family Salticidae (Araneae) from Viet-Nam. Ann. zool., Warszawa, 39: 197-485. 